\title{
KAJIAN MUTU IKAN TONGKOL (Euthynnus Affinis) ASAP UTUH YANG DIKEMAS VAKUM DAN NON VAKUM SELAMA 2 HARI PENYIMPANAN PADA SUHU KAMAR
}

\author{
Deliaspriake Buntu Kaiang ${ }^{1}$, Lita A.D.Y. Montolalu² dan Roike I. Montolalu² \\ 1) Mahasiswa pada Program Studi Teknologi Hasil Perikanan FPIK Unsrat Manado \\ ${ }^{2)}$ Staf pengajar pada Program Studi Teknologi Hasil Perikanan FPIK Unsrat Manado \\ Email: deliasbuntu_25@yahoo.com
}

\begin{abstract}
ABSTRAK
Ikan merupakan sumber protein, juga diakui sebagai functional food yang mempunyai arti penting bagi kesehatan karena mengandung asam lemak tak jenuh berantai panjang (terutama yang tergolong asam lemak omega-3), vitamin serta makro dan mikro mineral. Ikan asap merupakan salah satu produk olahan yang digemari konsumen baik di Indonesia maupun di mancanegara karena rasanya yang khas dan aroma yang sedap spesifik. Namun demikian proses pengasapan ikan di Indonesia masih dilakukan secara tradisional menggunakan peralatan yang sederhana, selain itu kurang memperhatikan aspek sanitasi dan higienis sehingga dapat memberikan dampak bagi kesehatan dan lingkungan. Kelemahan-kelemahan yang ditimbulkan oleh pengasapan tradisional antara lain kenampakan kurang menarik (hangus sebagian), kontrol suhu sulit dilakukan dan terjadi polusi udara.

Salah satu cara yang tepat untuk mempertahankan daya awet ikan tongkol (Euthynnus affinis) asap yaitu dengan dikemas vakum. Prinsip utama dari pengemasan vakum adalah pengeluaran khususnya $\mathrm{O}_{2}$ dari produk sehingga dapat memperpanjang masa simpan. Selanjutnya dimodifikasi dengan penyimpanan dingin untuk memperoleh hasil yang lebih baik.

Penelitian ini bertujuan untuk mengamati kemunduran mutu kimiawi ikan tongkol asap selama 0 hari dan 2 hari, penyimpanan pada suhu kamar yang dikemas vakum dan non vakum dengan pengujian mutu meliputi Kadar air, pH, Total Plate Count (TPC), Total Volatile Base Nitrogen (TVB-N), dan Organoleptik. Metode penelitian yang digunakan adalah metode eksperimen eksploratif yaitu mengungkapkan fakta-fakta berdasarkan permasalahan yang ada melalui hipotesa. Parameter yang digunakan dalam penelitian adalah uji Kadar Air, uji pH, uji TPC, uji TVB-N, dan uji Organoleptik.

Hasil penelitian yang diperoleh dari 5 parameter uji, diperoleh nilai kadar air tertinggi $(63,4 \%)$, terendah (63,85\%); nilai $\mathrm{pH}$ tertinggi 6,31 , terendah 5,87; nilai TVB tertinggi $(89,46 \mathrm{mg} \mathrm{N} / 100 \mathrm{~g})$, terendah $(36,54 \mathrm{mg} \mathrm{N} / 100 \mathrm{~g})$; nilai TPC tertinggi $(186,5 \times 102)$, terendah $(<30)$; nilai Organoleptik (Rasa) tertinggi (7,6), terendah (1.3); nilai Organoleptik (Kenampakan) tertinggi $(7,5)$, terendah $(5,0)$; Nilai Organoleptik (Bau) tertinggi $(7,3)$, terendah $(1,5)$; nilai Organoleptik (Tekstur) tertinggi $(7,2)$, terendah $(3,9)$.
\end{abstract}

Kata Kunci: Ikan Tongkol (Euthynnus affinis), asap, Kajian Mutu, TVB-N, pH, Kadar Air, TPC, Organoleptik.

\section{PENDAHULUAN}

Sub sektor perikanan merupakan andalan utama sumber pangan dan gizi bagi masyarakat Indonesia. Produksi perikanan Indonesia cukup besar, dan semakin meningkat setiap tahun, volume produksi perikanan tangkap (perikanan laut dan perairan umum) dan budidaya (air laut, tambak, kolam, karamba, jaring apung, sawah) pada tahun 2006 yaitu sebesar 7.488.708 ton, sedangkan pada tahun 2010 meningkat menjadi 10.826 .502 ton (KKP 2011). Hasil perikanan tersebut pada umumnya dikonsumsi dalam bentuk segar, diekspor dan diolah baik secara modern maupun tradisional. Produk hasil olahan tradisional dapat berupa ikan asin, ikan asap, ikan pindang, dan produk-produk fermentasi. Jumlah produksi ikan asap di Indonesia pada tahun 2007 mencapai 66.970 ton (JICA 2009), sedangkan produksi ikan asap (ikan fufu) di SULUT, sebanyak 31.408 ton, (DKP, SULUT 2012).

Ikan merupakan sumber protein, juga diakui sebagai functional food yang mempunyai arti penting bagi kesehatan karena mengandung asam lemak tak jenuh berantai panjang (terutama yang tergolong asam lemak omega3), vitamin serta makro dan mikro mineral. Menurut Mentang, $d k k$ (2011), asam lemak omega-3 (18:3n-3) dapat menurunkan kadar trigliserida dan total kolesterol dalam darah serta dapat meningkatkan metabolisme lemak.

Ikan asap merupakan salah satu produk olahan yang digemari konsumen baik di 
Indonesia maupun di mancanegara karena rasanya yang khas dan aroma yang sedap spesifik. Namun demikian proses pengasapan ikan di Indonesia masih dilakukan secara tradisional menggunakan peralatan yang sederhana, selain itu kurang memperhatikan aspek sanitasi dan higienis sehingga dapat memberikan dampak bagi kesehatan dan lingkungan. Kelemahan-kelemahan yang ditimbulkan oleh pengasapan tradisional antara lain kenampakan kurang menarik (hangus sebagian), kontrol suhu sulit dilakukan dan terjadi polusi udara (Swastawati, 2011).

Pengasapan dapat didefinisikan sebagai proses penetrasi senyawa volatil pada ikan yang dihasilkan dari pembakaran kayu yang dapat menghasilkan produk dengan rasa dan aroma spesifik masa simpan yang lama karena aktivitas antibakteri, menghambat aktivitas enzimatis pada ikan sehingga dapat mempengaruhi kualitas ikan asap. Senyawa kimia dari asap kayu umumnya berupa fenol (yang berperan sebagai antioksidan), asam organik, alkohol, karbonil, hidrokarbon dan senyawa nitrogen seperti nitro oksida, aldehid, keton, ester, eter, yang menempel pada permukaan dan selanjutnya menembus ke dalam daging ikan (Isamu, $d k k$. 2012). Ikan tongkol asap yang diproduksi di Sulawesi Utara yang berada dipasaran, banyak mendapat perhatian dari para ahli untuk diteliti, untuk ikan tongkol asap utuh masih jarang dan bahkan belum diteliti. Berdasarkan pertimbangan tersebut maka peneliti merasa perlu untuk mengetahui mutu ikan tongkol asap utuh yang dikemas vakum.

\section{METODOLOGI PENELITIAN}

\section{Tempat dan Waktu Pelaksanaan Penelitian}

Sampel diambil dari salah satu penjual ikan yang berada di Pasar Bahu. Kemudian analisis sampel dan penelitian dilaksanakan di Laboratorium Pengendalian Mutu Hasil Perikanan, Fakultas Perikanan dan Ilmu Kelautan, UNSRAT. Penelitian ini dilaksanakan pada bulan September 2015.

\section{Bahan dan Alat Penelitian}

Bahan baku yang digunakan dalam penelitian ini adalah ikan tongkol (Euthynnus affinis) asap utuh yang di ambil dari salah satu penjual ikan di pasar bahu Malalayang Manado. Bahan Plastik Polyetilen (Kris) $(28 \times 40 \mathrm{~cm})$, bahan kimia yang di gunakan adalah $\mathrm{K}_{2} \mathrm{CO}_{3}$ jenuh, TCA 7,5\%, Larutan Indikator (methyl red dan bromo cresol green), Asam borat $\left(\mathrm{H}_{3} \mathrm{BO}_{3}\right)$, Asam Klorida (HCL $\left.0,02 \mathrm{~N}\right)$, Vaselin, Nutrient Agar (NA), $\mathrm{NaCl} 0,9, \mathrm{pH}$ 7, dan akuades.

Alat-alat yang digunakan dalam penelitian ini antara lain adalah : timbangan analitik, oven, Erlenmeyer, Magnetik stirrer, tabung reaksi, spatula, pipet steril, beaker glass, gelas ukur, cawan petri, autoclave, laminar flow, inkubator, wadah penyimpanan/piring, pisau, tissue, mortar, $\mathrm{pH}$-meter, kertas saring whattman no.2, cawan conway, pipet, corong kaca, cawan porselin, alat penjepit, desikator, silika gel, oven, dan mikroburet.

\section{Perlakuan}

Perlakuan yang dilakukan dalam penelitian ini yaitu:

Waktu penelitian diasumsikan dilakukan pada waktu yang sama di setiap hari. Ulangan yang dilakukan sebanyak 2 kali.

A. Perlakuan pengemasan

$\mathrm{A}_{1}$ : Pengemasan plastik Vakum

$\mathrm{A}_{2}$ : Pengemasan plastik non Vakum

B. Lama penyimpanan

$\mathrm{B}_{1}$ : 0 Hari,

$\mathrm{B}_{2}$ : 2 Hari,

\section{Parameter Yang Diamati \\ Analisis Kadar Air}

Menurut Sudarmadji, $d k k$. (1989). Kadar air ditentukan dengan menghitung kehilangan berat dari sampel yang dipanaskan. Prosedurnya adalah sebagai berikut:

1. Cawan porselin dan penutupnya dibersihkan kemudian dikeringkan dan dioven pada suhu $105-110^{\circ} \mathrm{C}$ selama $1 \mathrm{jam}$, selanjutnya didinginkan dalam desikator selama 30 menit dan ditimbang beratnya (A).

2. Sampel ditimbang sebanyak $2 \mathrm{~g}$ dalam cawan porselin yang sudah diketahui beratnya (B). Sampel dalam cawan porselin ini kemudian dikeringkan dalam oven pada suhu $\quad 105-110^{\circ} \mathrm{C}$ selama 24 jam, selanjutnya didinginkan dalam desikator selama 30 menit dan ditimbang (C).

3. Penimbangan ini dilakukan berulang-ulang sampai diperoleh berat yang konstan. Persentase kadar air dapat dihitung dengan rumus :

$$
\text { Kadar air }=\frac{(B-C)}{(B-A)} \times 100 \%
$$




\section{Analisa Tingkat Keasaman (pH)}

Penentuan derajat keasaman $\mathrm{pH}$ dapat dilakukan dengan menggunakan $\mathrm{pH}$ meter (Suwetja, dkk. 2007). Adapun tahapan kerja sebagai berikut:

1. Timbang sampel yang telah dirajah kecilkecil sebanyak $20 \mathrm{~g}$ dan dihomogenkan (diblender) dengan $4 \mathrm{ml}$ akuades selama 1 menit.

2. Tuangkan ke dalam beker gelas $10 \mathrm{ml}$, kemudian di ukur pH-nya dengan menggunakan $\mathrm{pH}$ meter.

3. Sebelum $\mathrm{pH}$ meter digunakan, harus ditata jarum petunjuk $\mathrm{pH}$ meter dengan larutan buffer $\mathrm{pH}$, kemudian dengan larutan buffer $\mathrm{pH} 7$.

4. Besarnya nilai $\mathrm{pH}$ adalah pembacaan jarum petunjuk $\mathrm{pH}$ setelah jarum skala konstan kedudukannya.

\section{Analisis Total Volatile Base (TVB-N)}

Metode analisa Total Volatile Base

(TVB) ditetapkan dengan metode Conway. Oleh Suwetja (1993) Sebagai berikut:

1. Lima (5) g daging ikan, dihancurkan dengan menambahkan $10 \mathrm{ml}$ larutan Trichloroacetic Acid (TCA) 7,5\%.

2. Setelah hancur rata, sampel ikan disaring dengan kertas saring (no.2-3).

3. Sebanyak $1 \mathrm{ml}$ larutan asam borat $\left(\mathrm{H}_{3} \mathrm{BO}_{3}\right)$ $1 \%$ dan beberapa tetes larutan indikator (methyl red dan bromo cresol green) dipipet ke inner chamber.

4. Kemudian $1 \mathrm{ml}$ larutan ekstrak daging ikan dipipet ke outer chamber.

5. Setelah itu, penutup cawan yang permukaannya telah diolesi rata dengan vaselin, diletakkan pada rumahnya dengan posisi sedikit terbuka.

6. Selanjutnya, $1 \mathrm{ml} \mathrm{K}_{2} \mathrm{CO}_{3}$ jenuh dipipet ke outer chamber bagian lain.

7. Kemudian cawan ditutup rapat dan diputar perlahan sampai larutan sampel bercampur dengan $\mathrm{K}_{2} \mathrm{CO}_{3}$ jenuh. Blanko dibuat dengan mengganti larutan ekstraksi daging ikan dipakai larutan TCA.

8. Cawan disimpan dalam suhu kamar selama 24 jam. Dititrasi bagian inner chamber dengan menggunakan larutan asam klorida (HCl) 0,02 N. Titik akhir titrasi adalah pada saat asam borat kembali berwarna merah muda kemudian dicatat berapa banyak $(\mathrm{ml})$ asam klorida yang digunakan untuk mentitrasi.

\section{Total Bakteri (TPC)}

Pengujian mikrobiologi pada produk perikanan dengan menggunakan Total Plate Count (TPC) bertujuan untuk mengetahui jumlah bakteri total yang terdapat dalam produk yang diujikan mengacu pada SNI 01-2332.32006 (BSN 2006). Penghitungan jumlah koloni bakteri merupakan salah satu uji yang penting dalam menilai mutu suatu bahan pangan, karena selain dapat menduga daya tahan suatu makanan juga dapat digunakan sebagai indikator sanitasi atau keamanan makanan (Fardiaz 1996). Berikut prosedur pengujian mikrobiologi berupa penentuan Angka Lempeng Total (ALT):

1. Sampel sebanyak $10 \mathrm{~g}$ daging ikan yang telah dihaluskan dimasukkan ke dalam botol berisi $90 \mathrm{ml} \mathrm{NaCl}$ 0,9\% kemudian dikocok sampai homogen sehingga didapatkan pengenceran $10^{-1}$.

2. Larutan contoh dipipet $1 \mathrm{ml}$ dan dimasukkan ke dalam tabung reaksi yang berisi $9 \mathrm{ml} \mathrm{NaCl} 0,9 \%$ untuk memperoleh pengenceran $10^{-2}$, demikian seterusnya sampai diperoleh contoh dengan pengenceran $10^{-4}$ dan larutan dibiarkan selama 10 menit.

3. Masing-masing pengenceran, dipipet $1 \mathrm{ml}$ dan dimasukkan ke dalam cawan petri yang steril.

4. Media-agar NA (Nutrien Agar) dituangkan $10 \mathrm{ml}$ ke cawan petri dan segera ditutup lalu diputar melingkar atau membentuk angka delapan secara perlahan supaya media-agar tersebut merata.

5. Setelah media-agar membeku, cawan petri dibungkus kertas lalu disimpan dengan posisi terbalik dalam inkubator dengan suhu $37^{\circ} \mathrm{C}$ selama maksimal $2 \times 24$ jam. Penghitungan jumlah koloni bakteri dilakukan setelah masa inkubasi dengan colony counter.

\section{Organoleptik}

Uji Organoleptik adalah cara penilaian dengan hanya menggunakan indra manusia (sensorik). Penilaian organoleptik merupakan cara yang paling banyak dilakukan dalam menentukan mutu atau tanda-tanda kesegaran ikan karena muda dalam pengerjaannya serta peralatan yang digunakan relatif murah. (Hadiwiyoto, 1993). Salah satu cara mengetahui respon konsumen terhadap suatu produk yang dievaluasi adalah dengan cara pengujian 
sensorik, yaitu pengujian yang dipakai sebagai alat untuk menilai, mengukur menganalisa dan menginterpretasikan reaksi-reaksi yang timbul sebagai hasil pandangan, penciuman, rasa dan perabaan suatu produk (Rumpon, 2002).

Berhimpon, (2002) untuk pengujian organoleptik digunakan uji tingkat kesukaan (hedonik) untuk nilai rasa. Contoh diberi nomor kode dan disajikan secara acak. 15 orang panelis diminta menilai menurut tingkat kesukaannya berdasarkan skala hedonik yang telah disediakan pada formulir. Setiap panelis menandai ungkapan pada formulir yang sesuai dengan penilaiannya terhadap contoh.

Uji organoleptik/mutu hedonik ikan tongkol asap utuh dinilai berdasarkan pada kriteria yaitu kenampakan, tekstur, rasa, dan Bau.

\section{Analisa Data}

Data yang diperoleh dalam penelitian selanjutnya dilakukan perhitungan dengan nilai rata-rata, kemudian hasilnya disajikan dalam bentuk tabel. Sedangkan hasil pengamatan yang bersifat kuantitatif disajikan dalam bentuk histogram.

\section{HASIL DAN PEMBAHASAN}

\section{Kadar Air}

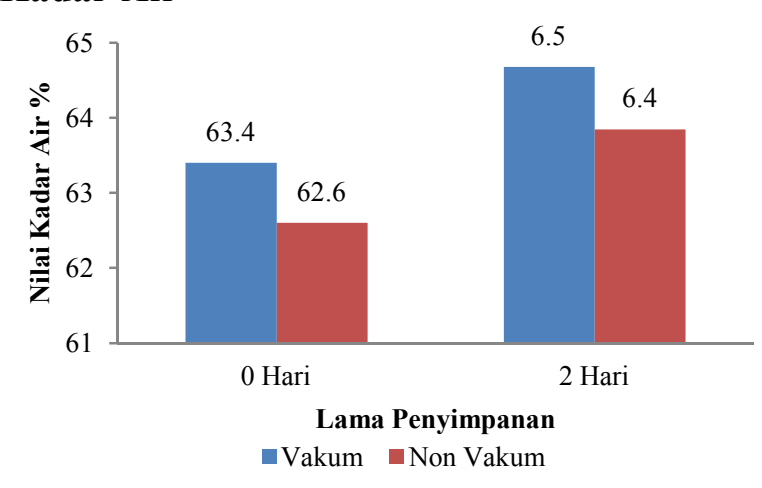

Gambar 1. Nilai Kadar Air Ikan tongkol
(Euthynnus affinis) Asap dengan
variasi pengemasan dan lama
penyimpanan.

Berdasarkan hasil penelitian, diperoleh nilai rata-rata kadar air ikan tongkol asap pada penyimpanan 0 hari yang dikemas vakum adalah $63,4 \%$ dan non vakum adalah $62,6 \%$. Pada penyimpanan 2 hari nilai rata-rata kadar air ikan tongkol asap yang dikemas vakum adalah $64,7 \%$ dan non vakum adalah $63,8 \%$. Hubungan nilai rata-rata kadar air Ikan tongkol asap selama penyimpanan yang dikemas vakum dan tanpa pengemas dapat dilihat pada Gambar 1.

Dari gambar tampak bahwa nilai kadar air sampel ikan tongkol asap selama penyimpanan mengalami kenaikan nilai kadar airnya. Dari gambar dapat dilihat, pada produk yang dikemas vakum mengalami kenaikan nilai kadar air yang sangat signifikan dibandingkan dengan produk yang tidak dikemas vakum. Peningkatan kadar air ini disebabkan terserapnya uap air di lingkungan sekitar walaupun telah dikemas dengan bahan pengemas plastik tetapi karena plastik memiliki sifat permeabel terhadap uap air maka akan memudahkan uap air masuk (terserap) ke dalam ikan. Tingginya kadar air pada bahan yang dikemas menyebabkan terjadi kelembaban yang tinggi dalam plastik sebagai pengemas dan menyebabkan mikroba dapat tumbuh dengan cepat. Hal ini karena adanya perbedaan tekanan di dalam dan di luar kemasan akan mengakibatkan masuknya uap air ke dalam kemasan dan uap air tersebut diserap oleh produk sehingga menaikkan kadar air produk selama penyimpanan (Ishak dan Amrullah, 1984). Winarno (1980), menyatakan bahwa kadar air suatu produk dipengaruhi oleh kelembaban nisbi udara sekelilingnya. Jika kelembaban ruang lebih tinggi, produk akan menyerap air, dan bila kelembaban ruang penyimpanan rendah produk akan menguapkan airnya.

Standar nilai kadar air ikan asap berdasarkan SNI adalah maksimal 60-65\%. Hasil penelitian menunjukkan produk ikan asap yang dikemas vakum dan tanpa pengemas selama penyimpanan 2 hari memiliki kadar air masih batas standar yang telah ditentukan oleh SNI. Kadar air merupakan parameter yang penting untuk menentukan kualitas ikan asap yang dihasilkan. Kadar air yang terkandung di dalam ikan asap dapat mempengaruhi daya simpan ikan asap. Karena kadar air merupakan media mikroba untuk berkembang biak (Agus, dkk. 2014).

\section{Penentuan Derajat Keasaman (pH)}

Berdasarkan hasil penelitian, diperoleh nilai rata-rata $\mathrm{pH}$ ikan tongkol asap selama penyimpanan pada pengemas vakum dan non vakum. Nilai rata-rata $\mathrm{pH}$ ikan tongkol asap pada 0 hari penyimpanan yang dikemas vakum adalah 5,87 dan non vakum adalah 5,83. Nilai 
rata-rata $\mathrm{pH}$ Ikan tongkol pada penyimpanan 2 hari yang dikemas vakum yaitu 6,17 dan non vakum yaitu 6,31 . Hubungan nilai rata-rata $\mathrm{pH}$ Ikan tongkol asap selama penyimpanan produk yang dikemas vakum dan non vakum dapat dilihat pada gambar 2 .

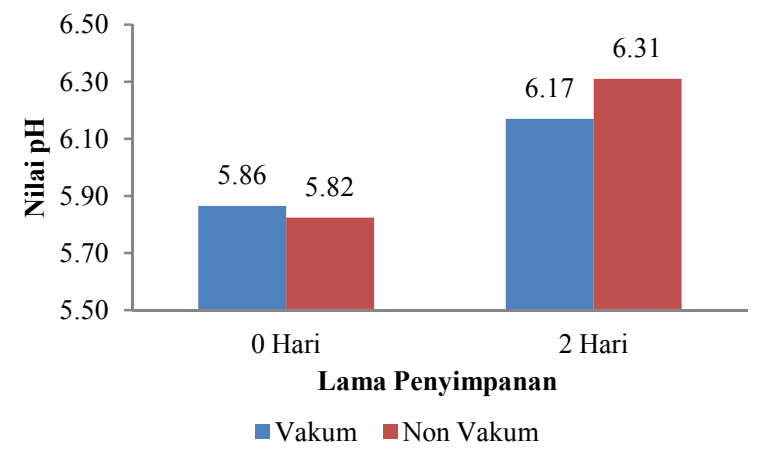

Gambar 2. Nilai pH ikan tongkol (Euthynnus affinis) Asap dengan variasi pengemasan dan lama penyimpanan.

Dari Gambar 2 menunjukkan bahwa nilai $\mathrm{pH}$ untuk lama penyimpanan 0 hari ikan yang dikemas vakum 5,87 dan non vakum 5,83 sedangkan untuk penyimpanan 2 hari mengalami peningkatan yaitu untuk ikan yang divakum 6.17 dan non vakum 6.31. Dari histogram di atas terlihat bahwa selama penyimpanan ikan asap utuh yang dikemas vakum dan non vakum mengalami peningkatan nilai $\mathrm{pH}$ pada hari ke 2. Daging ikan yang mempunyai nilai $\mathrm{pH}$ tinggi disebabkan karena timbulnya senyawa-senyawa yang bersifat basa seperti amoniak, trimetilamin, dan senyawasenyawa volatile lainnya yang juga dapat menurunkan nilai organoleptik dari produk (Hadiwiyoto 1993).

Kenaikan nilai pH kemungkinan disebabkan karena ikan tongkol asap utuh pada waktu pengolahan tidak mengalami penyiangan, padahal sumber bakteri pada ikan adalah pada perut, insang dan kulit. Jika ikan tidak disiangi dan hanya dicuci 1 x maka bakteri tetap ada dan berkembang. Kepadatan bakteri pada insang $10^{3}-10^{5} / \mathrm{g}$, pada kulit $10^{2}-10^{6} / \mathrm{g}$ dan pada perut $10^{3}-10^{7} / \mathrm{g}$ (Afrianto-Liviawaty, 1989). Walaupun pada kulit tidak menutup kemungkinan peluang masih terdapat sejumlah bakteri.

Berdasarkan data nilai $\mathrm{pH}$ menunjukkan bahwa ikan yang dikemas vakum dan non vakum pada penyimpanan hari ke 2 menunjukkan nilai $\mathrm{pH}$ yang merupakan media yang baik untuk pertumbuhan mikro organisme.
Menurut Fardias (1982) pH yang baik untuk ikan yang diawetkan antara 2,0-5,6 sedangkan pH 6,0-8,0 merupakan media yang baik untuk pertumbuhan mikroorganisme.

\section{Analisis Total Volatile Base (TVB)}

Berdasarkan hasil penelitian, diperoleh nilai rata-rata TVB ikan tongkol asap selama penyimpanan pada pengemas vakum dan non vakum. Nilai rata-rata TVB-N Ikan tongkol (Euthynnus affinis) Asap pada 0 hari penyimpanan yang dikemas vakum adalah $36,54 \mathrm{mg} \mathrm{N} / 100 \mathrm{~g}$ sampel dan non vakum adalah $36,54 \mathrm{mg} \mathrm{N} / 100 \mathrm{~g}$ sampel. Nilai rata-rata TVB$\mathrm{N}$ pada penyimpanan hari ke-2 yang dikemas vakum yaitu $85,68 \mathrm{mg} \mathrm{N} / 100 \mathrm{~g}$ sedangkan non vakum adalah $89,46 \mathrm{mg} \mathrm{N} / 100 \mathrm{~g}$ sampel. Hubungan nilai rata-rata $\mathrm{pH}$ Ikan tongkol asap selama penyimpanan pada produk yang dikemas vakum dan non vakum dapat dilihat pada gambar 3 .

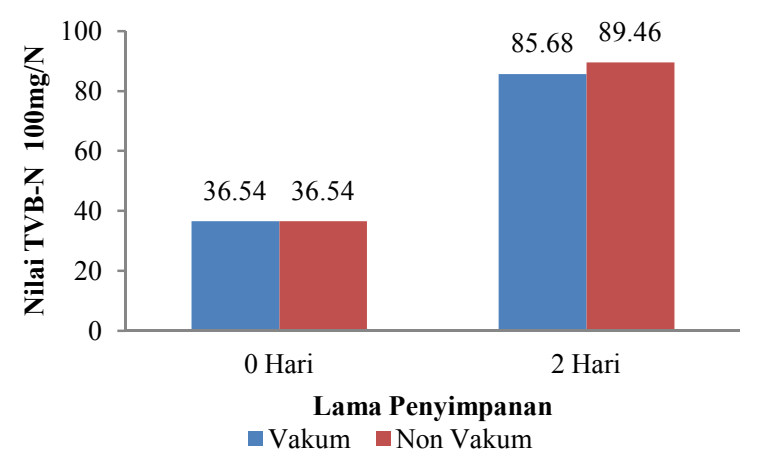

\section{Gambar 3. Nilai TVB-N Ikan tongkol (Euthynnus affinis) Asap dengan variasi pengemasan dan lama penyimpanan.}

Dari gambar terlihat kandungan TVB-N produk yang dikemas vakum dan non vakum mengalami peningkatan selama penyimpanan. Peningkatan terjadi karena kemungkinan aktivitas enzim pengurai mulai bekerja. Meningkatnya senyawa basa dipengaruhi oleh pertumbuhan bakteri yang selama penyimpanan ikut juga meningkat. Menurut Suwetja (1993), kerja bakteri dalam merombak protein dan asam-asam amino menjadi senyawa-senyawa yang lebih sederhana untuk dapat tumbuh dan berkembang biak menghasilkan senyawasenyawa sisa seperti $\mathrm{NH}_{3}$, trimetilamin dari senyawa-senyawa turunannya dimana senyawasenyawa ini termasuk golongan basa-basa menguap. TVB-N digunakan sebagai batasan yang layak dikonsumsi. 
Dari penelitian ini nilai rata-rata Total Volatile Base dari produk yang dikemas vakum dan non vakum yang disimpan selama 2 hari penyimpanan masih dalam kriteria yang baik dan produk ini masih layak untuk dikonsumsi. Batas pembusukan dari produk ikan olahan (ikan yang dikeringkan dan digarami) menurut SNI adalah 100-120 mg N/100g. Yunizal $d k k$. (1994) menyatakan keadaan dan jumlah kadar TVB-N tergantung pada mutu kesegaran ikan makin mundur mutu ikan kadar TVB-N akan meningkat jumlahnya.

\section{Total Plate Count (TPC)}

Berdasarkan pengamatan nilai TPC diperoleh nilai rata-rata Ikan tongkol asap selama penyimpanan pada pengemas vakum dan non vakum dapat dilihat pada Tabell.

Tabel 1. Data Hasil Pengamatan Nilai TPC

\begin{tabular}{|c|c|c|c|c|c|}
\hline & $\begin{array}{l}\text { Perla- } \\
\text { kuan }\end{array}$ & $\begin{array}{c}\text { Ulang- } \\
\text { an }\end{array}$ & $\begin{array}{l}\text { Jumlah } \\
\text { Koloni }\end{array}$ & $\begin{array}{l}\text { Nilai } \\
\text { TPC }\end{array}$ & ket \\
\hline \multirow{2}{*}{$\begin{array}{l}\text { A1 } \\
\text { (0 hari) }\end{array}$} & $\begin{array}{c}\text { B1 } \\
\text { (vakum) }\end{array}$ & $\begin{array}{l}1 \\
2\end{array}$ & $\begin{array}{r}5 \times 10^{2} \\
59 \times 10^{1}\end{array}$ & $32 \times 10^{3}$ & $>30$ \\
\hline & $\begin{array}{c}\mathrm{B} 2 \\
\text { (non vakum) }\end{array}$ & $\begin{array}{l}1 \\
2\end{array}$ & $\begin{array}{l}68 \times 10^{2} \\
58 \times 10^{1}\end{array}$ & $63 \times 10^{3}$ & \\
\hline \multirow{2}{*}{$\begin{array}{l}\text { A2 } \\
\text { (2 hari) }\end{array}$} & $\begin{array}{c}\text { B1 } \\
\text { (vakum) }\end{array}$ & $\begin{array}{l}-1 \\
2\end{array}$ & $\begin{array}{l}161 \times 10^{1} \\
125 \times 10^{2}\end{array}$ & $143 \times 10^{3}$ & $>30$ \\
\hline & $\begin{array}{c}\text { B2 } \\
\text { (non vakum) }\end{array}$ & $\begin{array}{l}1 \\
2\end{array}$ & $\begin{array}{l}165 \times 10^{2} \\
208 \times 10^{1}\end{array}$ & $186,5 \times 10^{3}$ & \\
\hline
\end{tabular}

Dari data tersebut dapat dilihat pada produk yang dikemas vakum masih terlihat lebih sedikit koloni bakteri yang tumbuh dibandingkan produk yang tidak dikemas vakum. Hasil penelitian selama penyimpanan terjadi peningkatan nilai TPC pada produk yang vakum dan non vakum. Peningkatan ini bisa disebabkan pada saat pengambilan sampel hari ke-0 penanganan ikan dari tempat pengolah kurang memperhatikan sanitasi dan hygiene selama pengolahan hingga produk akhir, sehingga dapat mengontrol terjadinya kontaminasi dan perkembangbiakan mikroba. Menurut Moeljanto (1992), baik dan buruknya penanganan sangat menentukan mutu ikan sebagai bahan mentah untuk pengolahan lebih lanjut. Mutu dari suatu produk akhir akan ditentukan oleh keadaan sanitasi dan hygiene dari bahan mentah, selama pengolahan hingga menjadi produk akhir (IIyas, 1972). llyas (1983), pertumbuhan bakteri pada ikan sangat dipengaruhi oleh suhu, semakin rendahnya suhu ikan semakin lambat pertumbuhan bakteri. Selanjutnya selama penyimpanan akan terjadi perubahan dekomposisi baik oleh flora bakteri maupun oleh enzim proteolitik. Ketersediaan oksigen juga membatasi pertumbuhan mikroba akan terhambat. Pada penyimpanan 2 hari terjadi peningkatan nilai koloni bakteri, hal ini disebabkan bakteri dan kapang mulai bertumbuh dan berkembang biak. Hasil penelitian menunjukkan pada produk yang dikemas vakum menunjukkan jumlah bakteri lebih rendah, hal ini disebabkan karena tidak tersedianya oksigen untuk kebutuhan metabolisme dari bakteri, sehingga bakteri sulit untuk berkembang biak walaupun kadar air yang dikandung produk cukup untuk aktivitas bakteri. Dari hasil penelitian ini, produk yang dikemas vakum dan non vakum masih memenuhi syarat mutu ikan asap yang direkomendasikan oleh Badan Standar Nasional Indonesia (SNI 2725:1:2009) sampai penyimpanan ke-2 hari. Dimana batas maksimum nilai TPC adalah $1,0 \times 10^{5} \mathrm{koloni} / \mathrm{g}$. Dari data pada nilai TVB-N produk yang dikemas vakum dan non vakum mengalami peningkatan selama penyimpanan, dan pada nilai TPC produk yang dikemas vakum dan non vakum juga mengalami peningkatan pertumbuhan bakteri. Jadi hubungan antara TVB-N dan TPC berbanding lurus.

\section{Pengujian Organoleptik Rasa}

Berdasarkan hasil penelitian, diperoleh nilai rata-rata organoleptik (rasa) Ikan tongkol asap selama penyimpanan yang dikemas vakum dan non vakum dapat dilihat pada Gambar 4.

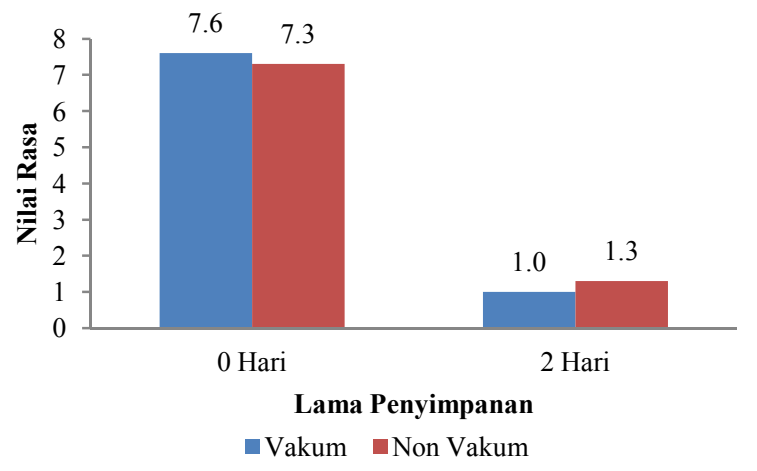

Gambar 4. Hasil penilaian panelis terhadap nilai organoleptik (Rasa) Ikan tongkol (Euthynnus affinis) Asap dengan variasi pengemasan dan lama penyimpanan.

Gambar 4 menunjukkan bahwa produk yang telah mengalami penyimpanan mengalami penurunan nilai organoleptiknya dari segi rasa. 
Hal ini dikarenakan ikan yang disimpan sudah ditumbuhi oleh jamur sehingga tingkat kesukaan panelis terhadap cita rasa menurun. Menurut Buckle, et al. (1987). lama penyimpanan dapat merubah cita rasa karena adanya penyimpangan bahan pangan pada saat mengalami reaksi atau perubahan sifat fisik dan kimia serta organoleptik sehingga ditolak oleh konsumen. Sehubungan dengan fakta dalam penelitian ini, panelis lebih menyukai produk ikan asap utuh yang dikemas vakum dan non vakum pada penyimpanan 0 hari.

Berdasarkan penilaian panelis nilai citarasa terbaik adalah pada produk yang dikemas vakum dengan lama penyimpanan 0 hari. Produk yang dikemas vakum dan non vakum dengan lama penyimpanan 2 hari, nilai organoleptik dari segi rasa sudah tidak disukai panelis. Nilai persyaratan mutu ikan asap yang direkomendasikan menurut SNI yaitu minimal 7.

\section{Kenampakan}

Berdasarkan hasil penelitian, diperoleh nilai rata-rata organoleptik (kenampakan) Ikan tongkol asap selama penyimpanan untuk yang dikemas vakum dan non vakum dapat dilihat pada Gambar 5.

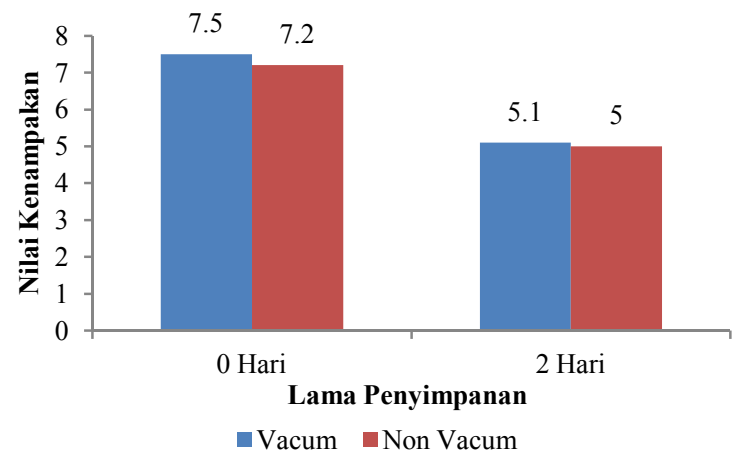

Gambar 5. Hasil penilaian panelis terhadap nilai organoleptik (Kenampakan) Ikan tongkol (Euthynnus affinis) Asap dengan variasi pengemasan dan lama penyimpanan.

Dari Gambar 5 menunjukkan bahwa semakin lama waktu penyimpanan menyebabkan nilai organoleptik dari segi kenampakan semakin menurun. Hal ini disebabkan oleh semakin tingginya kandungan air dalam tubuh ikan yang memungkinkan menguapnya senyawa-senyawa asap selama disimpan serta diakibatkan hampir seluruh bagian tubuh ikan sudah ditumbuhi oleh jamur sehingga kelihatan sudah tidak layak lagi.
Menurut Moeljanto (1992) menyatakan bahwa warna ideal dari ikan hasil proses pengasapan adalah warna kuning emas kecoklatan. Pada penelitian ini produk yang dikemas vakum dan non vakum dengan lama penyimpanan 0 hari, nilai organoleptik dari segi kenampakan masih disukai panelis, masih baik, masih terlihat menarik, bersih namun sudah agak kusam. Sedangkan penyimpanan 2 hari produk yang tidak dikemas vakum dan non vakum sudah tidak disukai oleh panelis. Nilai persyaratan mutu ikan asap yang direkomendasikan menurut SNI yaitu minimal 7.

\section{Bau}

Berdasarkan hasil penelitian, diperoleh nilai rata-rata organoleptik (bau) Ikan tongkol asap yang dikemas vakum dan non vakum selama penyimpanan suhu kamar dapat dilihat pada Gambar 6.

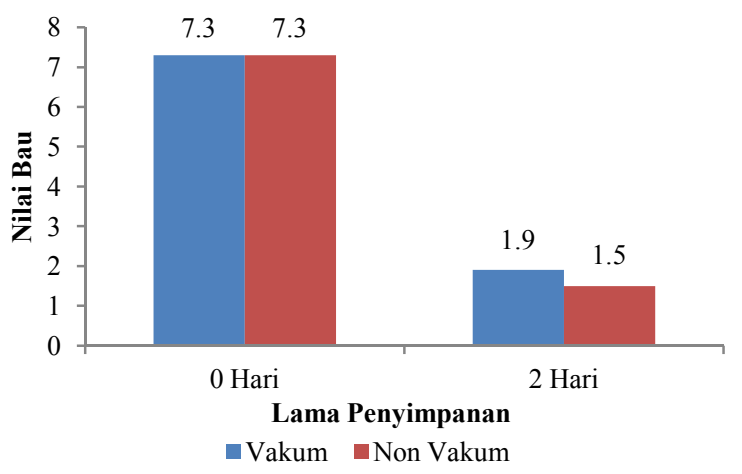

Gambar 6. Hasil penilaian panelis terhadap nilai organoleptik (Bau) Ikan tongkol (Euthynnus affinis) Asap dengan variasi pengemasan dan lama penyimpanan.

Gambar 6 menunjukkan bahwa lama penyimpanan sangat mempengaruhi nilai organoleptik dari segi bau ikan tongkol asap. Dari gambar dapat dilihat bahwa ikan yang dikemas dan tanpa dikemas dan disimpan selama 2 hari mengalami penurunan. Penurunan ini diakibatkan oleh timbulnya jamur pada ikan sehingga menyebabkan ikan mulai berbau tengik. Rata-rata panelis menilai ada sedikit bau tambahan pada produk ikan asap dan panelis menilai kurang harum. Kurangnya nilai bau tersebut diduga sebagai akibat pelepasan senyawa-senyawa lain yang tidak dikehendaki yang ikut bersama-sama di dalam asap.

$$
\text { Widiastuti (2007) menyatakan }
$$

kehadiran mikroorganisme pada ikan juga mengakibatkan perubahan bau. Bau tersebut timbul akibat timbulnya amoniak $\left(\mathrm{NH}_{3}\right)$ pada 
degradasi protein dan gas $\mathrm{H}_{2} \mathrm{~S}$ pada degradasi protein yang mengandung unsur sulfur oleh bakteri pembentuk gas $\mathrm{H}_{2} \mathrm{~S}$. Berdasarkan gambar di atas produk yang dikemas vakum dan tidak dikemas vakum dengan lama penyimpanan 2 hari, nilai organoleptik dari segi bau sudah tidak disukai panelis, hanya pada penyimpanan 0 hari produk baik yang dikemas vakum dan non vakum diminati panelis karena bau asap masih tercium dan produk masih baik. Nilai persyaratan mutu ikan asap yang direkomendasikan menurut SNI yaitu minimal 7.

\section{Tekstur}

Berdasarkan hasil penelitian, diperoleh nilai rata-rata organoleptik tekstur Ikan tongkol asap selama penyimpanan pada pengemas vakum dan tanpa pengemas dapat dilihat pada Gambar 7.

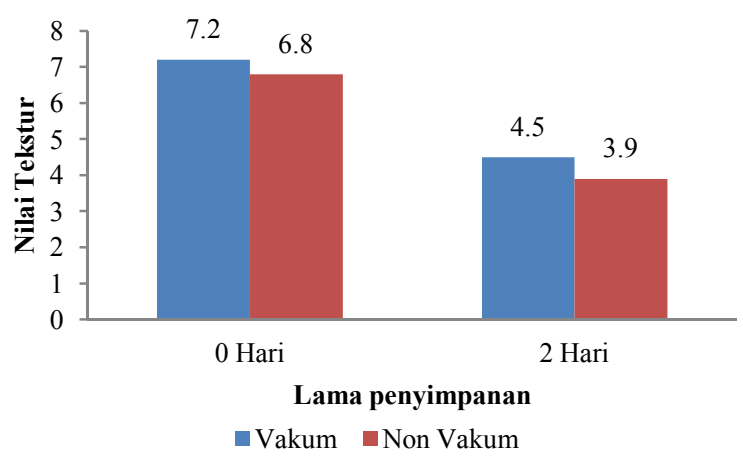

Gambar 7. Hasil penilaian panelis terhadap nilai organoleptik (Tekstur) Ikan tongkol (Euthynnus affinis) Asap dengan variasi pengemasan dan lama penyimpanan.

Dari Gambar 7 menunjukkan bahwa produk yang telah mengalami penyimpanan mengalami penurunan nilai organoleptiknya dari segi tekstur. Nilai tekstur suatu produk dipengaruhi juga oleh kadar air daging ikan yang segar dan perendaman dalam air garam dapat mengurangi kadar air, menghambat pertumbuhan mikroba, sehingga menyebabkan daging ikan lebih kompak, tekstur lebih baik dan disukai panelis, untuk produk ikan asap kemas vakum yang disimpan dingin teksturnya lembab disebabkan karena kadar air yang meningkat selama penyimpanan.

Menurut Purnomo (1995), penurunan nilai tekstur yang dimaksud adalah semakin rapuh daging ikan, tekstur produk ikan asap atau semakin keras atau keringnya produk karena salah satu parameter tekstur yang banyak dipakai ialah keempukkan, hal ini berkaitan dengan kebasahan, empuk, mudah terasanya cairan pada mulut saat produk dikunyah. Dari hasil penelitian ini produk ikan yang dikemas vakum dan non vakum sudah tidak disukai panelis sampai penyimpanan 2 hari. Nilai persyaratan mutu ikan asap yang direkomendasikan menurut SNI yaitu minimal 7.

\section{KESIMPULAN}

Berdasarkan hasil penelitian yang dilakukan, maka dapat ditarik kesimpulan sebagai berikut:

1. Berdasarkan hasil uji nilai kadar air, nilai TVB (Total Volatile Base), dan nilai TPC (Total Plate Count) Ikan tongkol (Euthynnus affinis) asap yang disimpan dengan pengemas vakum dan non vakum masih dalam kriteria mutu yang baik sampai pada 2 hari penyimpanan. Masih dalam kriteri yang baik menurut SNI (Standar Nasional Indonesia).

2. Berdasarkan hasil uji nilai $\mathrm{pH}$, Ikan tongkol (Euthynnus affinis) asap yang disimpan dengan pengemas vakum dan non vakum masih termasuk dalam kriteria mutu yang baik selama penyimpanan 0 hari, Pada penyimpanan 2 hari produk yang dikemas vakum dan tidak dikemas vakum sudah tidak baik.

3. Berdasarkan hasil uji organoleptik dari segi kenampakan, rasa, bau, dan tekstur, produk yang dikemas vakum dan non vakum masih disukai panelis sampai lama penyimpanan 0 hari, sedangkan pada penyimpanan ke- 2 hari, produk yang dikemas vakum dan non vakum sudah tidak diminati panelis.

\section{SARAN}

Perlu adanya penelitian lanjutan tentang Kajian Mutu Ikan Asap yang dikemas vakum dan non vakum pada suhu dingin.

\section{DAFTAR PUSTAKA}

Adawyah, R. 2008. Pengolahan dan Pengawetan Ikan. Penerbit. Bumi Aksara. Jakarta.

Afrianto dan Liviawaty. 1989. Pengawetan dan Pengolahan Ikan. Jogja: Penerbit Kanisius.

Agus. T.S.W., F. Swastawati, dan A.P. Anggo. 2014. Kualitas Ikan PAri (Dasyatis sp) Asap Yang Diolah Dengan Ketinggian Tungku Dan Suhu Yang Berbeda. Jurnal Pengolahan dan Bioteknologi Hasil Perikanan, vol 3. No.1 hal 147-156. 
Anonimous, http://duniachemistry.blogspot.co.id/2015/11/totalplatecount-tpc.html, November 20, 2015

Anonimous, 2010. Studi Pengembangan Dan Penerapan Teknik Pengasapn Ikan Tongkol Di Kabupaten Natuna. Laporan Akhir BPP-PSPL UNRI.

Berhimpon, S., H. Dien, R. Montolalu, 2002. Processing and The Prospect of Katsuobushi (Ikan kayu) of North Sulawesi, Indonesia: A Review. Fish Handling and Processing Laboratory.Faculty of Fisheries and Marine Science.Sam Ratulangi University. Manado

Buckle, 1987. Ilmu pangan. Penerjemah Hari purnomo, adiyono, (Ui-prets) jakarta

Dinas Kelautan Dan Perikanan. 2014. www.dkp.com

Dinas Kelautan dan Perikanan. 2012. www.dkp.com (13 Mei 2015).

Fardiaz, S. 1996. Prinsip HACCP dalam Industri Pangan. Bogor: Teknologi Pangan dan Gizi. Institut Pertanian Bogor, Bogor.

Fardias, S., 1982. Mikrobiologi pangan. Penuntun Praktek Laboratorium Institut Teknologi Pertanian.

Hadiwiyoyo, (1993). Teknologi Hasil Perikanan. Jilid 1. Penerbit Liberti Jakarta.

Haeldman. 2007. Handbook Of Food Engineering Second Edition (Edisi Terjemahan). Jakarta: Gramedia.

http://adecovilia.blogspot.com/2013/10/makalahpengolahan-pengasapan-ikan.html

IIyas, S, 1983. "Teknologi Refrigrasi Hasil Perikanan". Jilid 1. Teknik Pendinginan Ikan. C. V. Paripurna, Jakarta.

Irawan, A. 1995. Pengolahan Hasil Perikanan Home Industri, Usaha Perikanan dan Mengkomersilkan Hasil Sampingan. Cv. Aneka. Solo

Isamu Kobajashi T., Hari Purnomo dan Sudarminto S. Yuwono. 2012. Karakteristik Fisik, Kimia, Dan Organoleptik Ikan Cakalang (Katsuwonus Pelamis) Asap Di Kendari. Jurnal Teknologi Pertanian Vol.13 No. 2 [Agustus 2012] 105-110.

http://adecovilia.blogspot.com/2013/10/makalahpengolahan-pengasapan-ikan.html.

Mareta, Dea Tio dan A, Nur Shofia. 2011. Pengemasan Produk Sayuran dengan Bahan Kemas Plastik pada Penyimpanan Suhu Ruang dan Suhu Dingin. Jurnal Mediagro

Mentang, M., M. Maita, H. Ushio, T. Ohshima. 2011. Efficacy of Silkworm (Bombyx mori L.) Chrysalis Oil as a lipid source in adult Wistar rats. Food Chamistry 127(2). P. 899-904.

Moedjiharo, 2004. Hubungan kadar air dengan mutu ikan, teknologi industri hasil perikananfakultas perikanan dan ilmu kelautan universitas brawijayamalang

https://daniwara.wordpress.com/laporan-tfpp/. Laporan TFPP

Moeljanto, 1982. Pengolahan dan Pengawetan Hasil Perikanan. Penebar Swadaya. Jakarta.

Moeljanto, R. 1992. Pengawetan dan Pengolahan Hasil Perikanan. Penerbit Swadaya. Jakarta.

Munandar. 2009. Kemunduran Mutu IKan Nila Pada Penyimpanan suhu rendah. Universitas Sultan Ageng Tirtayasa. Serang.
Nastiti, Dwi. 2006. Kajian Peningkatan Mutu Produk Ikan Manyung (Arius Thalassinus) Panggang Di Kota Semarang. TESIS. Program Studi Magister Manajemen Sumberdaya Pantai.Program Pascasarjana. Universitas Diponegoro. Semarang

Nurjanah, 2002. Omega-3 dan Kesehalan, makalah pengantar fasafah sains Program Pasca Sarjana IPB, Bogor,

Pandit, Suranaya. 2008. Research of Cloride Test in Sulphate Acid Com modity. Fakultas Teknik Jurusan Kimia Universitas WR. Supratman. Surabaya.

Puspabuana, O, M. 2013. Pengolahan pengasapan ikan.

http://adecovilia.blogspot.com/2013/10/makalahpengolahan-pengasapan-ikan.html.

Rahayu, S., Nudinah, Nasran S., 1982. Pengaruh Penggaraman Pendahuluan Bahan Mentah Terhadap Mutu Produk Pindang, dalam ; Laporan Penelitian Teknologi Perikanan No.17 Tahun 1982. B.L.T.P. Jakarta.

Renate, Dharia. 2009. Pengemasan Puree Cabe Merah dengan Berbagai Jenis Plastik Yang Dikemas Vakum ( Packaging of Red Chilli Puree with Various Types of Plastic vacum Packaged ). Jurnal Teknologi Industri dan Hasil Pertanian.

Rustamadji. 2009. Persentase Kadar Air dan TMA. BFirst . Jakarta.

Rompon, S. 2002. Tingkat ketengikan ikan kakatua (Callyodon sp) asin bebrapa pasar di Manado. Skripsi, tdak di publikasikan. FPIK UNSRAT. Manado.

Saanin, (1984). Taksonomi dan kunci identifikasi ikan. Bina cipta,Jakarta.

Sanger, Grace. 2010. Oksidasi Lemak Ikan Tongkol (Auxfs Thazardl Asap Yang Direndam Dalam Larutan Ekstrak Daun Sirih. Pacific Journal Juli 2010 Vol 2 (5) : $870-873$

Sasmito, B.B. 2006. Dasar - dasar Pengawetan Bahan Pangan. Univarsitas Brawijaya. Malang.

Standard Nasional Indonesia (SNI). 2009. Ikan Asap Bagian 1. Spesifikasi. SNI 27 25.1:2009. Badan Standardisasi Nasional. Jakarta.

Sudarmadji, S. Bambang Haryono, Suhardi. (1989). Prosedur Analisa Untuk Bahan Makanan dan Pertanian.

Sunarsih, S., Y. Pratiwi., dan Y. Sunarto. 2012. Pengaruh Suhu, Waktu Dan Kadar Air Pada Pembuatan Asap Cair Dari Limbah Padat Pati Aren. Prosiding Seminar Nasional Aplikasi Sains dan Teknologi (SNAST) Periode III. Yogyakarta 3 November 2012. ISSN: 1979-911X.

Suwetja, I. K, J. Pongoh, O. Jumariah 2007. Penentuan rigormortis TMAO dan ATP. Diktat, Universitas Sam Ratulangi.

Suwetja, K. I. 1993. Metode Penentuan Mutu Ikan. Jilid I. Penentuan Kesegaran. Fakultas Perikanan dan Ilmu Kelautan. Universitas Sam Ratulangi. Manado

Swastawati, Fronthea. 2011. Studi Kelayakan Dan Efisiensi Usaha Pengasapan Ikan Dengan Asap Cair Limbah Pertanian. Fakultas Perikanan Dan Ilmu Kelautan Universitas Diponegoro. Semarang.

http://adecovilia.blogspot.com/2013/10/makalahpengolahan-pengasapan-ikan.html 
Tapatubun,et.al,(2000). Hubungan kadar air dengan mutu ikan. https://daniwara.wordpress.com/laporan-tfpp/ . Laporan TFPP

Widiastuti, I.M.2007. Sanitasi dan Mutu Kesegaran Ikan Konsumsi pada Pasar Tradisional Di Kotamadya Palu. Jurnal. Agroland 14 (1):77-81 ISSN: 0854-641X.

Winarno, F,G (2002). Hubungan kadar air dengan mutu ikan. https://daniwara.wordpress.com/laporan-tfpp/. Laporan TFPP

Yuliana, Neti 2007. Profil Fermentasi Rusip Yang Dibuat Dari Ikan Teri. Teknologi Hasil Perikanan. Universitas Lampung. Bandar Lampung. 